\title{
For a children's rights approach to obesity prevention: the key role of an effective implementation of the WHO Recommendations
}

\author{
Amandine Garde, Seamus Byrne, Nikhil Gokani and Ben Murphy
}

\section{Introduction}

As discussed above, there is strong and growing evidence that unhealthy food marketing influences preferences, purchase requests and consumption choices of children and, as such, contributes to childhood obesity, independently from other factors, i.e. irrespective of the fact that screen time may also increase snacking and physical inactivity. Nevertheless, the EU does not seem to have taken existing evidence on board, as the ongoing debates surrounding the revision of the AVMS Directive suggest. This contribution focuses on the role that the United Nations Convention on the Rights of the Child (the Convention) can play in preventing non-communicable diseases (NCDs) and childhood obesity. In particular, it argues that the EU and its Member States should implement the WHO Recommendations not only as a result of their international commitment to halt the rise of childhood obesity, but also as a matter of law under their obligations stemming from international human rights law, and the Convention more specifically.

This contribution argues that, even though the WHO Recommendations themselves do not refer to children's rights, their comprehensive implementation nonetheless supports a children's rights approach to childhood obesity prevention in that they flesh out the provisions of relevant international human rights instruments, and in particular Article 24 of the Convention which mandates States Parties to respect, protect and fulfil the child's right to the highest attainable standard of health.

After identifying the role of the Convention in the EU legal order (I), this contribution discusses the relevance of Article 24 of the Convention in the discussions surrounding the implementation of the WHO Recommendations (II) and how it should be balanced against potentially conflicting rights, such as the right to free expression which food business operators may invoke to oppose marketing restrictions (III).

\section{The Convention on the Rights of the Child in the EU legal order}

As the most ratified human rights instrument in the world, the Convention provides the basis for a normative children's rights approach to obesity and NCD prevention. Through its articulation of a wide array of rights and entitlements, exclusive to children, the Convention establishes a potent platform to regulate unhealthy food marketing to children by establishing State obligations and the responsibilities of other stakeholders, particularly business actors.

\section{Short introduction to the Convention}

The UN General Assembly adopted the Convention on 20 November 1989, and the Convention entered into force on 2 September $1990 .{ }^{1}$ In building on earlier children's rights

\footnotetext{
${ }^{1}$ UN General Assembly Resolution 44/25. The Convention has been ratified by all States in the world except the USA.
} 
statements - including the Declaration of Geneva 1924, the Declaration of the Rights of the Child 1959 and the International Year of the Child 1979 - the Convention represents a decade's long struggle to solidify the rights and entitlements of children as autonomous and independent beings.

Extensive in its scope, the Convention sets out an all-embracing array of civil, political, economic, social and cultural rights and represents 'a landmark in the history of childhood'. 3 With 54 articles and three optional protocols, ${ }^{4}$ the Convention constructs the legal foundations upon which State duties, and the responsibilities of non-State actors, towards children are configured. ${ }^{5}$ In its amalgamation of civil and political as well as social, economic and cultural rights, the Convention symbolises the indivisible and interrelated nature of all human rights. ${ }^{6}$ The Convention contains two main sections: Articles 1 to 41 lay down the rights it guarantees to all human beings below the age of 18 years, ${ }^{7}$ and Articles 42 to 54 deals with its entry into force and monitoring. The Committee on the Rights of the Child - the body of independent experts that monitors the implementation of the Convention and its protocols by State parties - has underlined four overarching provisions which constitute the guiding principles for interpreting other Convention articles:

- the obligation of States to respect and ensure the rights set forth in the Convention to each child within their jurisdiction without discrimination of any kind (Article 2);

- the best interests of the child as a primary consideration in all actions concerning children, whether undertaken by public or private social welfare institutions, courts of law, administrative authorities or legislative bodies (Article 3);

- the child's inherent right to life and States parties' obligation to ensure to the maximum extent possible the survival and development of the child development (Article 6); and

- the child's right to express his or her views freely in all matters affecting the child, those views being given due weight (Article 12). ${ }^{8}$

\footnotetext{
${ }^{2}$ For more, see generally P E Veerman, The Rights of the Child and the Changing Image of Childhood (Martinus Nijhoff Publishers 1992).

${ }^{3}$ M Freeman, Children's Rights: A Comparative Perspective (Dartmouth Publishing 1996), 1.

${ }^{4}$ These include the Optional Protocol on the involvement of children in armed conflict (A/RES/54/263, dated 25 May 2000), the Optional Protocol to the Convention on the Sale of Children, child prostitution and child pornography (A/RES/54/263, dated 25 May 2000) and the Optional Protocol on a communications procedure (A/RES/66/138 of 19 December 2011)

${ }^{5}$ For more see generally G Van Bueren, The International Law on the Rights of the Child (Martinus Nijhoff Publishers 1995). See also R Hodgin and P Newell, Implementation Handbook for the Convention on the Rights of the Child (UNICEF, 3rd edn 2007).

${ }^{6}$ According to the 1993 World Conference on Human Rights held in Vienna, 'all human rights are universal, indivisible and interdependent and interrelated. The international community must treat human rights globally in a fair and equal manner, on the same footing, and with the same emphasis. While the significance of national and regional particularities and various historical, cultural and religious backgrounds must be borne in mind, it is the duty of States, regardless of their political, economic and cultural systems, to promote and protect all human rights and fundamental freedoms.'

7 The definition of a child is provided by Article 1: 'for the purposes of the present Convention, a child means every human being below the age of eighteen years unless under the law applicable to the child, majority is attained earlier'.

${ }^{8}$ Committee on the Rights of the Child, General Comments N.5 (2003), CRC/GC/2003/5, 4.
} 
In its affirmation of children as individual rights holders, distinct from their parents, the Convention expounds a human rights approach which reflects the importance of children as social actors in their own right. ${ }^{9}$ The Convention also recognises that while children should be accorded a say in the realisation of their rights, ${ }^{10}$ developmental and evolutionary realities demand an approach which balances both children's rights on the one hand, and the obligations of parents and the State on the other, to uphold the enforcement of children's rights. Thus, while the Convention acknowledges child autonomy and its importance, it also recognises the implicit vulnerabilities attached to childhood. Therefore, the role of parents and the State, in all aspects of child development, assumes increased significance when viewed from the perspective of the Convention. This is particularly true in relation to the intersection of children's rights and unhealthy food marketing. Indeed, a children's rights approach to unhealthy food marketing offers a powerful and universal approach which puts children, as rights-holders, at the centre of policy discourse. This approach, reflecting and incorporating the provisions of the Convention, should be seen to complement, as opposed to exclude, existing approaches. ${ }^{11}$

A children's rights approach identifies children as rights-holders and States as the corresponding duty-bearers. A children's rights approach works towards strengthening the capacities of right-holders (children) to understand and realise their rights, and of duty-bearers (States) to meet their obligations. By imposing legal obligations on States, a children's rights approach guarantees a degree of State accountability, making effective remedies more likely where rights are violated. A human rights approach supports the monitoring of State commitments with the help of recommendations of human rights treaty bodies, and through public and independent assessments of performance. Thus, a children's rights approach has the potential to translate the commitments and obligations enshrined in the Convention into operable, durable and realisable entitlements. Furthermore, as children's rights are inalienable and universal, the language of human rights can ensure that a given issue is afforded special consideration in public policy: competing policies can be delegitimised if they are incompatible with children's rights. ${ }^{12}$

In September 2011, the UN General Assembly, in its Political Declaration on NCDs, reaffirmed 'the right of everyone to the enjoyment of the highest attainable standard of physical and mental health' and recognised 'the urgent need for greater measures at the global, regional and national levels...in order to contribute to the full realization of the right of everyone to the highest attainable standard of physical and mental health'. Similarly, the WHO's Global Action Plan for the Prevention and Control of Non-Communicable Diseases 2013-2020 places a human rights, equity-based principle at its core. A human rights approach is an essential policy option demanded from both States and international organisations, and can be especially useful in empowering communities and people. More recently, the WHO's Commission on Ending Childhood Obesity, in its final report, reaffirmed the essential relevance of the child's right to the highest attainable standard of health:

Government and society have a moral responsibility to act on behalf of the child to reduce the risk of obesity. Tackling childhood obesity resonates with the universal

\footnotetext{
${ }^{9}$ See generally, J Allison, C Jenks and A Prout, Theorizing Childhood (Polity Press 1998).

${ }^{10}$ See Articles 5 and 12 CRC.

${ }^{11}$ M Friant-Perrot and A Garde, L'impact du marketing sur les préférences alimentaires des enfants (Institut national de prévention et d'éducation pour la santé [INPES], 2014).

${ }^{12}$ A Garde, S Byrne, N Gokani and B Murphy, Food Marketing and Children's Rights (UNICEF, forthcoming, June 2017).
} 
acceptance of the rights of the child to a healthy life as well as the obligations assumed by State Parties to the Convention of the Rights of the Child.

UNICEF, and to a lesser extent the WHO Regional Office for Europe, have launched an indepth reflection on what a children's rights approach would imply for the regulation of unhealthy food marketing and the implementation of the WHO Recommendations. ${ }^{13}$ This contribution reflects on what the tools that the Convention provides in the European Union more specifically.

\section{The role of the Convention in the EU legal order}

In the first 40 years of its existence, the EU had paid hardly any attention to children's rights. The Treaty of Rome made no reference whatsoever to children. It is only following the adoption of the Treaty of Amsterdam that the first express reference to children was introduced in the EU Treaty, as Article K provided a basis for intergovernmental co-operation to tackle 'offences against children'. Nevertheless, this mention only concerned the cooperation of EU Member States in relation to such offences, without granting any new power of legislative harmonisation to the Union. ${ }^{14}$ Moreover, the only secondary legislation affecting children which was adopted in the early days of the Community involved the extension of the right to education and social and tax advantages which workers benefited from to their children so as to facilitate their movement from one Member State to another. ${ }^{15}$

The proclamation by the Heads of the Member States of the EU Charter in 2000 heralded a change of attitude towards children. The EU Charter was the first instrument giving some visibility to children's rights at EU level. Article 24 EU Charter is entirely dedicated to 'the Rights of the Child':

\footnotetext{
${ }^{13}$ A Garde, S Byrne, N Gokani and B Murphy, Food Marketing and Children's Rights (UNICEF, forthcoming, June 2017), and M Tatlow-Golden et al, Tackling food marketing to children in a digital world: transdisciplinary perspectives. Children's rights, evidence of impact, methodological challenges, regulatory options and policy implications for the WHO European Region (WHO Regional Office for Europe, 2016). There is also growing academic literature on this issue: J. Tobin, 'Beyond the Supermarket Shelf: Using a Rights Based Approach to Address Children's Health Needs', International Journal of Children's Rights 14(3) (2006) 275; A. Garde, 'Advertising Regulation and the Protection of Children-Consumers in the European Union: In the Best Interest of... Commercial Operators?', in H. Stalford et al (eds), Children's Rights in Europe, a Special Issue of the International Journal of Children's Rights 19 (2011) 523; A. Garde, 'The Best Interest of the Child and EU Consumer Policy: A Major Gap between Theory and Practice?', in J. Devenney and M. Kenny (eds), The Theory and Practice of EU Consumer Law and Policy (Cambridge University Press, 2012), 164; L. Mills, 'Selling Happiness in a Meal: Serving the Best Interests of the Child at Breakfast, Lunch and Supper', International Journal of Children's Rights 20 (2012) 624; E. Handsley et al., 'A Children's Rights Perspective on Food Advertising to Children', International Journal of Children's Rights 22 (2014) 93; and K. O'Cathaoir, 'Childhood Obesity and the Right to Health', Health and Human Rights Journal 18 (2016) 249.

${ }^{14}$ The Amsterdam Treaty contained other developments of relevance to children, even though they did not have children as their direct focus: Article 13 EC introduced a non-discrimination clause empowering EU institutions to adopt legislation on various equality grounds, including age; Article 137(j) EC introduced a legal basis for combating social exclusion, and tackling child poverty has become a key objective for EU action. More generally, Article 6(2) TEU reaffirmed the EU's commitment to fundamental rights (which include children's rights). Following the entry into force of the Lisbon Treaty, Article 13 EC, Article 137 EC and Article 6 TEU have been renumbered Article 19 TFEU, Article 153 TFEU and Article 6 TEU, respectively.

${ }^{15}$ See in particular Articles 12 and 7(2) of Regulation 1612/68 (OJ 1968 L 257/2). Claire McGlynn has argued that children were seen as an obstacle to the proper functioning of the Internal Market, rather than as individuals in their own right: C McGlynn, 'Rights for Children? The Potential Impact of the European Union Charter of Fundamental Rights' (2002) 8 European Public Law 387, 388. See also H Stalford, 'The Developing European Agenda on Children's Rights' (2000) 22 Journal of Social Welfare and Family Law 229, 234.
} 
1. Children shall have the right to such protection and care as is necessary for their wellbeing. They may express their views freely. Such views shall be taken into consideration on matters which concern them in accordance with their age and maturity.

2. In all actions relating to children, whether taken by public authorities or private institutions, the child's best interests must be a primary consideration.

3. Every child shall have the right to maintain on a regular basis a personal relationship and direct contact with both his or her parents, unless that is contrary to his or her interests. $^{16}$

Article 24 incorporates several principles of the Convention, not least by requiring that the best interests of the child shall be considered across all policy areas relating to children (subject to the constitutional principle of conferral ${ }^{17}$ ). As the European Commission noted, 'if fully implemented, this represents a significant step towards "child-proofing" of EU legislation and policy'. ${ }^{18}$ However, the EU Charter does not expressly refer to the Convention (and Article 3 more specifically). This raises the question of the extent to which EU institutions are bound by its provisions and by the recommendations and interpretative guidance of the Committee on the Rights of the Child. The case law of the Court of Justice of the European Union (CJEU), the European Commission's Communication Commission Communication of 4 July 2006 establishing a long-term EU strategy to effectively promote and safeguard the rights of the child in EU policies and to support Member State's efforts in this field ${ }^{19}$ as well as the Lisbon Treaty all strongly suggest that the Convention should be seen as a reference point in determining how the EU and its Member States should ensure that the best interests of the child is upheld as a primary consideration in all EU policies. Accordingly, children's rights now 'occupy an increasingly prominent place on the EU legal and policy agenda'. ${ }^{20}$

The CJEU referred to the Convention for the first time in Council v Parliament (Family Reunification Directive) in June 2006, ${ }^{21}$ where it recognised that the Convention provided a source of the general principles of EU law. ${ }^{22}$ Since then however, the ascendancy of

\footnotetext{
${ }^{16}$ Several other articles of the EU Charter advance the situation of children at EU level. On the role which the EU Charter could play to give more prominence to children's rights in the EU legal order, see C McGlynn, 'Rights for Children? The Potential Impact of the European Union Charter of Fundamental Rights'(2002) 8 European Public Law 387; see also H Cullen, 'Children's Rights' in S Peers and A Ward (edss), The EU Charter of Fundamental Rights (Hart 2004).

${ }^{17}$ The EU Charter applies only to areas which fall within the scope of EU competence, as explicitly stated in Article 51. Thus, the situation still is that major policy areas affecting children, including the administration of juvenile justice or the legality of corporal punishments, remain within the remit of Member States' powers and are not therefore directly affected by the Article 24. Nevertheless, Member States are all signatories to the CONVENTION and, as such, bound to uphold the best interests of the child principle laid down in Article 3(1).

18 'Preliminary Inventory of EU Actions Affecting Children's Rights Commission', Staff Working Document Accompanying the Communication from the Commission 'Towards and EU Strategy on the Rights of the Child', SEC (2006) 889, 3.

${ }^{19}$ COM (2006) 367 final. The Commission Communication provides explicitly that the provisions of the CONVENTION must be fully taken into account: at par. I.3.

${ }^{20}$ H. Stalford (2015), The CRC in litigation under EU Law, in T .Liefaard and\& Jaap E .Doek (2011) Litigating the Rights of the Child: The UN Convention on the Rights of the Child in Domestic and International Jurisprudence, (Springer Publishers 2015), pp 211 -- 230.

${ }^{21}$ Case C-540/03 Parliament v Council [2006] ECR I-5769.

${ }^{22}$ Three Advocates General had referred to the Convention in their opinions prior to the Court's judgment in Parliament v Council: AG Stix-Hackl on 13 September 2001 in Case C-459/99 MRAX [2002] ECR I-6591; AG
} 
children's rights and the related centrality which it brings to judicial decision-making ${ }^{23}$ has also permeated, the function of the CJEU. In Dynamic Medien Vertriebs GmbH. V Avided Media $A G^{24}$ the Court, in determining the legality of German labelling restrictions on items which had already been subject to such controls in the UK, held that the German constraints constituted a valid interference with the EU's freedom of goods provisions. Specifically, in reaching its determination that freedom of expression can concede to the limitations imposed by security, public order, public health and morals, the Court, in referring to Article 17 of the Convention affirmed the duty of States to develop appropriate guidelines for the protection of children from material injurious to their well-being. ${ }^{25}$ Notwithstanding these cases and the explicit references to children's rights in the EU Charter, the CJEU has been hesitant to 'engage in any meaningful consideration of children's rights issues, even in matters which fall squarely within its competence'. ${ }^{26}$ In calling for the Court to 'embrace' the Convention in a more fulsome way, Stalford argues that such a step would stimulate dialogue between the Member States pertaining to the uniform application of children's rights measures. ${ }^{27}$ However, despite the hesitancy displayed by the Court in adjudicating on substantive children's rights matters, it has, on occasion, both directly and indirectly, referred to and incorporated children's rights principles into a number of its decisions. The Court has interwoven children's rights principles into its determinations across several policy areas, including child abduction ${ }^{28}$, third-party parental rights of Union citizens ${ }^{29}$ and custody matters impacting children. ${ }^{30}$

In July 2006, the European Commission adopted its Communication establishing a long-term EU strategy to effectively promote and safeguard the rights of the child in all EU's internal and external policies and to support Member State's efforts in this field. ${ }^{31}$ The Commission Communication provided explicitly that the provisions of the Convention must be fully taken into account ${ }^{32}$ and acknowledged (at last) that 'the idea of creating children friendly societies within the EU cannot be separated from the need to further deepen and consolidate European integration'. ${ }^{33}$ It went on to recognise that an enormous gap exists between the good intentions of international treaties and the real-life conditions of poverty, neglect and exploitation that millions of children worldwide are forced to endure and that, in spite of progress achieved in some areas, much remains to be done, ${ }^{34}$ stressing that the EU could bring essential and fundamental added value in the field of children's rights in both its internal and its external policies: 'there is thus an urgent need for a comprehensive EU strategy to increase

\footnotetext{
Jacobs on 22 May 2003 in Case C-148/02 Garcia Avello [2003] ECR I-11613; and AG Kokott on 11 November 2004 in Case C-105/03 Criminal Proceedings Against Maria Pupino [2005] ECR I-5285 and on 8 September 2005 in Parliament $v$ Council.

${ }^{23}$ For example, the Convention has established itself as an indispensable adjudicative tool to the European Court of Human Rights. For more on this question, see generally, U Kilkelly, The CRC in litigation under the ECHR in T Liefaard and J E Doek Litigating the Rights of the Child (Springer 2015); U Kilkelly, The Best of Both World's for Children's Rights: Interpreting the European Convention on Human Rights in light of the UN Convention on the Rights of the Child (2001) 23(2) Human Rights Quarterly 308.

${ }^{24}$ Case C-244/06 [2008] ECR 1 - 505

${ }^{25}$ Ibid para 92

${ }^{26}$ Above $\mathrm{n}(20)$ at $\mathrm{p} 229$

27 Ibid

${ }^{28}$ C-491/10 PPU, Aguirre Zarraga v Pelz, 22 December 2010.

${ }^{29}$ C-34/09, Gerardo Ruiz Zambrano v Office national de l'emploe (ONEM), 8March 2011.

${ }^{30}$ C-400/10, PPU, J.McB v L.E., 5 October 2010 \& C-497/10 PPU, Mercredi v Chaffe, (22 December 2010).

${ }^{31} \mathrm{COM}(2006) 367$ final.

${ }^{32}$ Commission Communication, at paragraph I.3.

${ }^{33}$ Commission Communication, at paragraph I.2.

${ }^{34}$ Commission Communication, at paragraph I.4.
} 
the scale and effectiveness of EU commitments to improve the situation of children globally and to demonstrate real political will at the highest possible level to ensure that the promotion and protection of children's rights get the place they merit on the EU's agenda'. ${ }^{35}$

The Commission Communication has increased the visibility of children as a group of citizens whose specific rights and interests must be protected at EU level. It has created an impetus reflected in the recent adoption of a range of measures which have the protection of children as their main focus (not least on cyber-crime, sexual exploitation, child trafficking, child poverty and social inclusion), ${ }^{36}$ and has recognised more generally that the EU has a role to play in promoting the best interests of the child in all its policies.

The Lisbon Treaty went one step further. Not only does it give the same legal value of the Treaties to the Charter, but it also proclaims the respect for children's rights as one of the EU's main objectives. Article 3 TEU provides as follows:

1. The Union's aim is to promote peace, its values and the well-being of its peoples...

3. The Union shall establish an internal market... It shall combat social exclusion and discrimination, and shall promote social justice and protection, equality between women and men, solidarity between generations and protection of the rights of the child...

5. In its relations with the wider world, the Union shall uphold and promote its values and interests and contribute to the protection of its citizens. It shall contribute to... the protection of human rights, in particular the rights of the child, as well as to the strict observance and the development of international law, including respect for the principles of the UN Charter. ${ }^{37}$

Since the entry into force of the Lisbon Treaty, children's rights have become a more visible and potent presence within EU policy. With the advent of EU enlargement and integration and the increased recognition of values such as citizenship and solidarity, children's rights have migrated from a peripheral position into the core of EU policy. ${ }^{38}$ Since Lisbon, a number of important EU strategies and policies have further centralised children's rights within the legal, mechanical and operational make-up of the EU. The 2011 Commission Communication 'An EU Agenda for the Rights of the Child' ${ }^{39}$ set out eleven discrete areas to enhance and promote child safety and well-being, ranging from judicial training to guarantee effective child participation in legal matters to enhancing best practice for those working with unaccompanied children. Similarly, the Europe 2020 Strategy, ${ }^{40}$ which set out the vision for EU economic progression in the aftermath of economic contraction and fiscal turmoil across

\footnotetext{
${ }^{35}$ Commission Communication, at paragraph II.1.

${ }^{36}$ For a discussion of these measures, see in particular H Stalford and E Drywood, 'Coming of Age?: Children's Rights in the European Union' (2009) 46 Common Market Law Review 143.

${ }^{37}$ Emphasis added.

${ }^{38}$ For more on the role of the EU in promoting and advancing children's rights, see H Stalford and I Iusman (eds), The EU as a Children;s Rights Actor: Law, Policy and Structural Dimensions (Barbara Budrich Publishing, 2015).

${ }^{39}$ European Commission (2011), Communication from the Commission to European Parliament, the Council, the European Economic and Social Committee and the Committee of the Regions, An EU Agenda for the Rights of the Child, COM (2011) 60,14.

${ }^{40}$ European Commission (2010) Communication from the Commission, Europe 2020, A Strategy for Smart, Sustainable and Inclusive Growth, COM (2010) 2020.
} 
many Member States, also recognised the role of children through the importance which the Strategy attached to the roles of education, training and the elimination of poverty. ${ }^{41}$ More recently however, and in response to the escalating refugee and migration crisis affecting Europe as a result of both inter and intra State violence across the Middle East and North African regions, the EU has directly acknowledged the immediate impact of such realities on children. Through the adoption of the Action Plan on Unaccompanied Minors $(2010-2014)^{42}$ and the recent acceptance of the revised EU Guidelines for the Promotion and Protection of the Rights of the Child $(2017)^{43}$ which affirm and consolidate children's rights within the EU's external human rights policy, children's rights have been further centralised within EU policy.

However, despite these positive policy developments for children, the EU does not seem to have adopted a children's rights approach to the regulation of food marketing to children.

\section{The effective implementation of the WHO Recommendations and the child's right to the highest attainable standard of health}

The right to the enjoyment of the highest attainable standard of health (right to health) is a universal human right. It is protected by Article 24 of the Convention, as well as several other international human rights instruments. ${ }^{44}$ Article 24 requires that 'States Parties recognise the right of the child to the enjoyment of the highest attainable standard of health and to facilities for the treatment of illness and rehabilitation of health'. ${ }^{45}$ The Committee on the Rights of the Child has issued a General Comment on Article $24,{ }^{46}$ whilst the Committee on Economic, Social and Cultural Rights has done the same in relation to Article 12 of the International Covenant on Economic, Social and Cultural Rights. ${ }^{47}$ These provide interesting insights concerning the scope of the right to health and its relevance to the implementation of the WHO Recommendations.

The right to health has a broad scope, drawing on the Constitution of the WHO which defines health as 'a state of complete physical, mental and social well-being, rather than merely the

\footnotetext{
${ }^{41}$ Specifically, the Strategy envisages that by 2020 the share of early school leavers should be under $10 \%$ and at least $40 \%$ of the younger generation should have a tertiary degree. The Strategy also stipulates that by 202020 million fewer people should be at risk of poverty.

${ }^{42}$ European Commission (2010) Communication from the Commission to the European Parliament and Council, Action Plan on Unaccompanied Minors $(2010$ - 2014). This plan set out three key objectives pertaining to children including;

1. The Prevention of Unsafe Migration and Trafficking

2. Recognition and Procedural guarantees in the EU

3. Identification of Durable Solutions

43 These guidelines, also referred to as the Leave No Child Behind Policy, were adopted by the European Council at its $3525^{\text {th }}$ meeting held on the $6^{\text {th }}$ March 2017.

${ }^{44}$ United Nations Convention on the Rights of the Child (1989). See, further, human rights instruments of general application: Universal Declaration of Human Rights (1948), art 25(1); International Covenant on Economic, Social and Cultural Rights (1966), art 12. See, also instruments addressing the human rights of specific groups: International Convention on the Elimination of All Forms of Racial Discrimination (1965), art 5(e)(iv); Convention on the Elimination of All Forms of Discrimination against Women (1979), art 12; International Convention on the Protection of the Rights of All Migrant Workers and Members of Their Families (1990), arts 28, 43(e) and 45(c); Convention on the Rights of Persons with Disabilities (2006), art 25.

${ }^{45}$ At paragraph 1.

${ }^{46}$ General Comment No 15 (2013) on the right of the child to the enjoyment of the highest attainable standard of health (article 24), $\mathrm{CRC} / \mathrm{C} / \mathrm{GC} / 15$.

${ }^{47}$ General Comment No 14 (2000) on the right of everyone to the enjoyment of the highest attainable standard of physical and mental health (article 12), E/C.12/2000/4.
} 
absence of disease or infirmity' ${ }^{48}$ The Committee on the Right of Child interprets the child's right to health as 'an inclusive right, extending not only to timely and appropriate prevention, health promotion, curative, rehabilitative and palliative services, but also to a right to grow and develop to their full potential and live in conditions that enable them to attain the highest standard of health through the implementation of programmes that address the underlying determinant of health'. ${ }^{49}$ As such, the right to health has an important role to play in the prevention of diseases, including NCDs which can only be effectively prevented if the environments in which children live are durably changed to promote healthier choices. ${ }^{50}$ The wording of Article 24 CRC supports such a wide interpretation of the right to health and its relevance to NCD and obesity prevention. ${ }^{51}$ In particular, Article 24(2) refers to the duty of States 'to take appropriate measures to diminish infant and child mortality' and 'to combat disease and malnutrition, through, inter alia, the provision of adequate nutritious foods'. This interpretation is reinforced by the need for States to interpret the CRC in a dynamic manner and address health concern affecting children at a given point in time, and not at the time the Convention was adopted when obesity was not seen as a major global public health issue. ${ }^{52}$ States are therefore encouraged to prioritise issues that have received little attention to date and should ensure, inter alia, the availability of 'safe and nutritionally adequate food' and 'a healthy and safe environment'. ${ }^{5}$

The right to health also requires that States consider child health through a life-course approach, starting from the neonatal stage to childhood through adolescence and into adulthood. 'The stages of the child's development are cumulative and each stage has an impact on subsequent phases, influencing the children's health, potential, risks and opportunities. Understanding the life course is essential in order to appreciate how health problems in childhood affect public health in general. ${ }^{54}$ This interpretation is very much in line with the approach which the WHO Commission on Ending Childhood Obesity urged Member States to adopt when developing policies intended to halt the rise of childhood overweight and obesity. ${ }^{55}$

Similarly, the notion of the 'highest attainable standard of health' takes into account both the child's biological, social, cultural and economic conditions and the resources available to the State, supplemented by resources made available by other sources, including NGOs or the international community. Even though the right to health is not a right to be healthy as such, it nonetheless amounts to a right to the conditions and services that ensure the enjoyment of the best health standards attainable under existing circumstances. Consequently, it mandates States to provide equality of opportunity for every child to enjoy the highest attainable standard of health (as opposed to any standard of health). States must fulfil children's right to health to the maximum extent of their available resources and, where needed, within the

\footnotetext{
${ }^{48}$ Preamble to the Constitution of the WHO as adopted by the International Healthy Conference, New York, 22 July 1946: http://apps.who.int/gb/bd/PDF/bd47/EN/constitution-en.pdf.

${ }^{49}$ General Comment No 15 (2013), at paragraph 1.

${ }^{50}$ This was forcefully reiterated in World Health Organization, 'Report of the Commission on Ending Childhood Obesity' (WHO, January 2016).

${ }^{51}$ As Tobin notes, this stems clearly not only from the text of Article 24 itself, but also from the drafting history of the CRC: J Tobin, The Right to Health in International Law (Oxford University Press 2012), 131.

52 'Children's health is affected by a variety of factors, many of which have changed during the past 20 years and are likely to continue to evolve in the future', including NCDs: General Comment No 15 (2013), at paragraph 5.

${ }^{53}$ UN Human Rights Office of the High Commissioner, The right of the child to the highest attainable standard of health (2013), at paragraph 99.

${ }^{54}$ General Comment No 15 (2013), at paragraph 20. See also the report of the UN Special Rapporteur on the Right to Health, Dainius Puras, of 2 April 2015, A/HRC/29/33, at paragraph 86.

${ }^{55}$ Recommendation 1.2.
} 
framework of international cooperation. ${ }^{56}$ In particular, this requires that States develop, implement and regularly monitor national programmes addressing the underlying determinants of health, including unhealthy diets and other NCD risk factors. ${ }^{57}$ As the Committee on the Rights of the Child has recognised, 'most mortality, morbidity and disabilities among children could be prevented if there were political commitment and sufficient allocation of resources directed towards the applicable of available knowledge and technologies for prevention, treatment and care'. ${ }^{58}$

In light of the unequivocal evidence linking unhealthy food marketing to childhood obesity, which is discussed in a separate paper above, the argument should be made that States should, as part of their duty to respect, protect and fulfil the right to health, ${ }^{59}$ implement the WHO Recommendations and restrict such marketing with a view to reducing its negative impact on children and the enjoyment of their right to health. There is a growing number of statements from various UN Agencies and Special Rapporteurs to this effect. For example, the Committee on the Rights of the Child has noted that the food industry spends billions of dollars on persistent and pervasive marketing strategies promoting unhealthy food to children, and that children's exposure to 'fast-foods' should be limited and their marketing, 'especially when it is focused on children', should be regulated and their availability in schools and other places controlled. ${ }^{60}$ This has been echoed by several other UN agencies and Special Rapporteurs. ${ }^{61}$

One of the most powerful statements relating to the relationship between the right to health and unhealthy food marketing to children was made in 2014 by Anand Grover, then UN Special Rapporteur on the Right to Health:

Owing to the inherent problems associated with self-regulation and public-private partnerships, there is a need for States to adopt laws that prevent companies from using insidious marketing strategies. The responsibility to protect the enjoyment of the right to health warrants State intervention in situations when third parties, such as food companies, use their position to influence dietary habits by directly or indirectly

\footnotetext{
${ }^{56}$ More generally, Article 4 provides that 'with regard to economic, social and cultural rights, States Parties shall undertake such measures to the maximum extent of their available resources and, where needed, within the framework of international co-operation'. On the relationship between budgetary decision-making and the CRC, and child rights-based budget analysis, see A Nolan, 'Economic and Social Rights, Budgets and the Convention on the Rights of the Child' (2013) 21 International Journal of Children's Rights 248.

${ }^{57}$ See, for example, the resolution of the Human Rights Council on the right of the child to the enjoyment of the highest attainable standard of health, 17 April 2013, A/HRC/22/32, at paragraph 28.

${ }^{58}$ General Comment No 15 (2013), at paragraph 1.

59 The obligation of States to respect, protect and fulfil human rights has become an increasingly accepted typology of duties, especially with respect to economic, social and cultural rights. Its roots can be traced to Asbjørn Eide, then Special Rapporteur of the Sub-Commission on the Promotion and Protection of Human Rights of the UN Commission on Human Rights, whose three-fold framework has become the substructure upon which State duties towards the realization of their obligations are both founded on and assessed against. UN Commission on Human Rights, 'Final Report submitted by A. Eide, Special Rapporteur on the Right to Adequate Food as a Human Right, The Right to Adequate Food as a Human Right' (1987) UN Doc. E/CN.4/Sub.2/1987/23. The ESC Committee has subsequently extended this typology to other rights, including the right to health in its General Comment 14 where the ESC Committee extended the obligation to fulfil to contain 'obligations to facilitate, provide and promote'. ESC Committee, General Comment No 14: The Right to the highest Attainable Standard of Health (11 August 2000) UN Doc E/C.12/2000/4, at para 33.

${ }^{60}$ General Comment No 15 (2013), at paragraph 47.

${ }^{61}$ See for example the statement by the Special Rapporteur in the field of Cultural Rights, 8 August 2014 , A/69/286: 'many products, behaviours and attitudes promoted by commercial advertising are harmful to people's health and social relationships, as well as to the environment'.
} 
encouraging unhealthy diets, which negatively affect people's health. Therefore, States have a positive duty to regulate unhealthy food advertising and the promotion strategies of food companies. Under the right to health, States are especially required to protect vulnerable groups such as children from violations of their right to health. ${ }^{62}$

This statement followed the similarly powerful statement that Olivier De Schutter, then UN Special Rapporteur on the Right to Food, made in September 2011:

It is unacceptable that when lives are at stake, we go no further than soft, promotional measures that ultimately rely on consumer choice, without addressing the supply side of the food chain. [...] Food advertising is proven to have a strong impact on children, and must be strictly regulated in order to avoid the development of bad eating habits early in life. ${ }^{63}$

Both Anand Grover and Olivier De Schutter unequivocally condemned the promotion of selfregulation as an adequate strategy to protect the right to health and urged States to ban unhealthy food marketing to children. As noted above, the EU's dogmatic belief in the virtues of self-regulation does not rest on any solid evidence - in fact all evidence points to the ineffectiveness of self-regulation of unhealthy food marketing - and, by not ensuring that the WHO Recommendations are implemented so that the impact of unhealthy food marketing is effectively limited, arguably violates the right to the child to the highest attainable standard of health.

Furthermore, in his more recent report on sport and healthy lifestyles as contributing factors to the right to health ${ }^{64}$ Dainius Puras, current UN Special Rapporteur on the Right to Health, noted that States should ensure full compatibility between sport policies, rules, programmes and practices, and human rights law, and should intensify their efforts to prevent systemic and ad hoc rights violations perpetrated by third parties. ${ }^{65}$ Sport can promote health and prevent diseases and provide an opportunity to promote human rights. ${ }^{66}$ However, this can only be so if policy coherence and effectiveness is ensured. As a result, the UN Special Rapporteur called on States to adopt laws limiting the marketing of tobacco and unhealthy food and beverages in school-based sporting activities and at professional sporting events'. ${ }^{67}$ Furthermore, he urged States to 'ban the advertising, promotion and sponsorship of all children's sporting events, and other sporting events which could be attended by children, by manufacturers of alcohol, tobacco and unhealthy foods' ${ }^{68}$ This report, which refers specifically to the WHO Recommendations, illustrates very convincingly how the WHO Recommendations promote a rights-based approach by requesting States to restrict unhealthy food marketing to children, particularly in settings where children gather. When powers are shared between the EU and its Member States, the EU should exercise its competence to

\footnotetext{
${ }^{62}$ Report on 'Unhealthy foods, non-communicable diseases and the right to health' presented at the 26th session of the Human Rights Council in June 2014, Document A/HRC/26/31, at paragraph 25.

${ }^{63}$ Report on 'The Right to an Adequate Diet: the Agriculture-Food-Health Nexus', presented at the 19th Session of the United Nations Human Rights Council, 26 December 2011, A/HRC/1/9/59.

${ }^{64}$ Report of the Special Rapporteur on sport and healthy lifestyles as contributing factors to the right to health of 4 April 2016, A/HRC/32/33.

${ }^{65}$ At paragraph 19.

${ }^{66}$ See in particular the resolution of the Human Rights Council on the right to health of 14 July 2014, $\mathrm{A} / \mathrm{HRC} / \operatorname{Res} / 26 / 18$.

${ }^{67}$ At paragraph 32.

${ }^{68}$ At paragraph 33.
} 
regulate the food industry when its marketing practices have cross-border implications, as would be the case for sports and cultural events of international appeal.

The UN Special Rapporteur has also focused on the specific needs of adolescents. ${ }^{69}$ In particular, he stressed that the online social media environment played an increasingly influential role in adolescents' lives, and suggested that 'lax legal frameworks governing the sale of tobacco, alcohol and fast foods' were not appropriate to address the challenges it posed. ${ }^{70} \mathrm{He}$ concluded that 'measures to address the right to health should be holistic and integrated, go beyond the provision of health services and be underpinned by crossdepartment commitment'. ${ }^{71}$

Even though the Committee on the Rights of the Child has not been as specific in its critique of unhealthy food marketing, it has nonetheless identified the issue and its relationship to childhood obesity as a major children's rights concern. An increasing number of Country Reports refer to childhood obesity as an issue negatively affecting the child's right to health, and the Committee has urged States - particularly those suffering from high rate of childhood obesity - to regulate the marketing of unhealthy food as part of their obligations under Article 24 CRC. $^{72}$

Overall, the WHO Recommendations put flesh on the bones of the right to health and guide Member States as to what they should be doing - individually and collectively as EU Member States - to respect, protect and fulfil the right to health and other related rights. They therefore support a children's rights approach, even though they do not themselves specifically refer to children's rights.

\section{The right to free expression and the 'best interest of the child' principle}

The 'best interests of the child' principle occupies a central position within the legal configuration of the Convention. Several academic commentators have argued that the best interests principle should be given a broad scope as 'it has the advantage of operating as a principle to be considered in relation to each of the rights in the Convention and importantly, residually, to all actions concerning children'. ${ }^{73}$ The wording of Article 3 Convention supports the view that the best interests of the child should be taken into consideration in all fields of policy, including consumer policy ('all areas of policy relevant to children'). So does the wording of Article $24 \mathrm{EU}$ Charter ('all areas relating to children'). ${ }^{74}$ The Committee on

\footnotetext{
${ }^{69}$ Report on the right of adolescents to the enjoyment of the highest attainable standard of health of 4 April 2016 , A/HRC/32/32.

${ }^{70}$ At paragraphs 35 and 36.

${ }^{71}$ At paragraph 37.

${ }^{72}$ See for example the latest report for Malta.

${ }^{73} \mathrm{G}$ Van Bueren, The International Law on the Rights of the Child (Save the Children 1995), 46. See also P Alston, 'The Best Interests Principle: Towards a Reconciliation of Culture and Human Rights' (1994) 8 International Journal of Law and the Family 1, 4.

${ }^{74}$ It has been noted that Article 24(2) Charter and Article 3 Convention are not identical to the extent that Article 24(2) states that the best interest principle will apply in all actions 'relating' to children, whereas Article 3 refers to all actions 'concerning' children. It is not clear whether this change is deliberate and how significant it might be in practice. Writing in 2002, Claire McGlynn argued that 'concerning' children may encompass many more indirect measures than the formulation 'relating to' children. If it seems clear that all policies, practices and other measures which have a direct impact on children will 'relate to' them, it is not so obvious for indirect measures. A measure may not have been adopted with children in mind, it might make no reference to children, but it might 'concern' children as it has an impact on them. Can it equally be said that the same measure 'relates' to children? A policy may be too general to be said to 'relate to' children, even if it is not child-neutral: C
} 
the Rights adopts a broad construction, referring to 'all legal revisions as well as in judicial and administrative decisions, and in projects, programmes and services which have an impact on children'. ${ }^{75}$ In 2013 the Committee on the Rights of the Child issued General Comment No. 14 specifically on this principle, ${ }^{76}$ where it asserted that the guarantee contained in Article 3 was 'aimed at ensuring both the full and effective enjoyment of all the rights recognized in the convention and the holistic development of the child'. ${ }^{77}$

Article 3 CRC extends the duty to have the child's best interests taken as a primary consideration to 'all actions' concerning children. This wording strongly supports the view that the best interests of the child should be interpreted broadly, ${ }^{78}$ covering all fields of policy, including consumer policy, and the regulation of unhealthy food marketing more specifically, as well as all stages of the policy process, from policy development to policy implementation, monitoring and evaluation. The Committee adopts a broad construction, referring to 'all legal revisions as well as in judicial and administrative decisions, and in projects, programmes and services which have an impact on children', ${ }^{79}$ covering 'not only decisions, but also all acts, conduct, proposal, services, procedures and other measures'. ${ }^{80}$ This includes 'actions directly affecting children (e.g. related to health services, care systems, or schools), as well as actions that indirectly impact on young children'. ${ }^{81}$ No policy is child-neutral. ${ }^{82}$

This approach seems to have been upheld by EU institutions - in theory if not in practice. The European Commission has stressed in its Communication of July 2006 the importance of mainstreaming children's rights into all EU policy areas. A dynamic interpretation of the principle is all the more warranted in light of the growing commercialisation of childhood and its impact on children's health and well-being. ${ }^{83}$ Furthermore, the principle of the best interests of the child applies to all institutions and bodies of the Union.

McGlynn, 'Rights for Children? The Potential Impact of the European Union Charter of Fundamental Rights' (2002) 8 European Public Law 387, 396. The Commission Communication seems to imply, however, that the difference in wording should not bear any consequences and that a broad understanding of Article 24 should be adopted, as it provides that 'it is important to ensure that all internal and external EU policies respect children's rights in accordance with the principles of EU law, and that they are fully compatible with the principles and provisions of the Convention and other international instruments', and that 'children's interests should be considered across all policy areas relevant to children' (Impact Assessment annexed to the Communication, at paragraph 3.2.1), which includes both direct and indirect measures - the degree of relevance being proportionate to the degree of directness of a given measure.

${ }^{75}$ Report on Benin in 1999, CR/C/15/Add. 106, at paragraph 14. Cited in M Freeman, 'Article 3: The Best Interests of the Child' in A Alen et al, A Commentary on the United Nations Convention on the Rights of the Child (Martinus Nijhoff Publishers 2007), 46.

${ }^{76}$ Committee on the Rights of the Child, General Comment No. 14 (2013).

${ }^{77}$ Committee on the Rights of the Child, General Comment No. 14 (2013) at paragraph 4

${ }^{78} \mathrm{G}$ Van Bueren, The International Law on the Rights of the Child (Save the Children 1995), 46. See also P Alston, 'The Best Interests Principle: Towards a Reconciliation of Culture and Human Rights' (1994) 8 International Journal of Law and the Family 1, 4.

${ }^{79}$ Report on Benin in 1999, CR/C/15/Add. 106, at paragraph 14. Cited in M. Freeman, 'Article 3: The Best Interests of the Child' in A. Alen et al., A Commentary on the United Nations Convention on the Rights of the Child (Martinus Nijhoff Publishers, 2007), 46.

${ }^{80}$ At paragraph 17.

${ }^{81}$ See Committee on the Rights of the Child (2009), General Comment No.7 on implementing child rights in early childhood, [13(b)]

${ }^{82} \mathrm{~S}$ De Vylder, 'Macroeconomic Issues and the Rights of the Child' in A Weyts (ed), Understanding Children's Rights: Collected Papers Presented at the Seventh International Interdisciplinary Course on Children's Rights (University of Ghent 2004), 431.

${ }^{83}$ A Garde, 'The Best Interests of the Child and EU Consumer Law and Policy: A Major Gap between Theory and Practice?' in J Devenney and M Kenny (eds), The Theory and Practice of EU Consumer Law and Policy (Cambridge University Press 2012), 164. 
As the Committee has stressed, 'the best interests of the child as a primary consideration becomes crucial when states are engaged in weighing competing priorities, such as short term economic considerations and longer term development decisions. The best interests of the child must be ' $a$ ' primary consideration in any decision-making process. Even though it is not 'the' primary consideration, ${ }^{84}$ in that the best interests of the child do not automatically override or supersede other considerations, the Committee has emphasized that the best interest standard must be allotted considerable and significant weight in any decision-making process. Consequently, any consideration which falls short of a primary consideration is incompatible with the spirit of the CRC: 'the child's best interests may not be considered on the same level as all other considerations, ${ }^{85}$ The determination of the best interests should be made on a case-by-case basis, bearing in mind that priority should be given not to any interests of the child but to his or her best interests. In relation to the marketing of unhealthy food to children more specifically, this means that the EU and its Member States should be very cautious before accepting the economic arguments put forward by food business actors, and in particular that their right to free expression and other commercial rights should prevent the comprehensive implementation of the WHO Recommendations.

As the Committee on the Rights of the Child has clearly stated, rhetorical statements that children's rights should be upheld cannot suffice. The means must be in place to ensure that they are effectively upheld:

Ensuring that the best interests of the child are a primary consideration in all actions concerning children (Article 3(1)), and that all the provisions of the Convention are respected in legislation and policy development and delivery at all levels of government demands a continuous process of child impact assessment (predicting the impact of any proposed law, policy or budgetary allocation which affects children and the enjoyment of their rights) and child impact evaluation (evaluating the actual impact of implementation). This process needs to be built into government at all levels and as early as possible in the development of policy. ${ }^{86}$

In the EU, all major policy initiatives require an integrated impact assessment which assesses potential economic, social and/or environmental impacts. This applies in particular to most legislation (proposed directives or regulations) and to White Papers, action plans, expenditure programmes and negotiating guidelines for international agreements. The European Commission has published a series of impact assessment guidelines which are intended to give general guidance to the Commission services for assessing potential impacts of different policy options. ${ }^{87}$ Unfortunately, children's rights are not singled out: they fall within the three broad categories of economic, social and environmental impact. There is therefore a risk that a proposal with a broad range of impacts fails to consider potential impacts of a policy on children. The constitutional obligation of EU institutions to uphold the best interests of the child as a primary consideration in all policy areas supports the argument that children's rights should be more clearly singled out. Moreover, it is necessary to ensure that child impact assessments are used to inform policy decisions, rather than to justify a preferred policy

\footnotetext{
${ }^{84}$ For more, See M Freeman, The Best Interests of the Child (Martinus Nijhoff Publishers 2007), 25-74.

${ }^{85}$ See footnote 16 at paragraph 37.

${ }^{86}$ Committee on the Rights of the Child, 2003, para 45.

87 <http://ec.europa.eu/smart-regulation/guidelines/toc_guide_en.htm>.
} 
option determined independently from the impact assessment process. ${ }^{88}$ This is all the more important if policy is to rely on evidence rather than assumptions. A rigorous, objective child impact assessment is likely to contribute to the acceptance, in the longer term, by food business actors, of the detrimental effects their commercial practices may have on children and the need to curb such practices to effectively uphold the best interests of the child as a primary consideration in all EU policies, including the core area of internal market policy. ${ }^{89}$

As we have already highlighted elsewhere, a stronger involvement of children's rights advocates is required at all stages of the policy process, from policy development, to policy implementation and to policy monitoring and evaluation. The mainstreaming of children's rights puts the onus on children's rights organizations to step outside their comfort zone and acquire the necessary expertise to influence the agenda in the interrelated fields of internal market and consumer policy, which they have not traditionally recognised as priority items in their work. They need to contribute to (if not prompt) the debate as to where the best interests of the child lie in all the policy areas falling within the scope of the powers conferred upon the EU by the EU Treaties. ${ }^{90}$

This should, in turn, allow for the use at national and EU levels of human rights - and Article 24 of the Convention children's rights more specifically - not only as a shield, to protect evidence-based policies from challenges from food business actors, but also as a sword, to actively pursue a regulatory agenda which fully complies with international human rights and does effectively uphold the best interests of the child as a primary consideration at all stages of the policy cycle and therefore comply with their obligations under international law, and the Convention more specifically. ${ }^{91}$

\footnotetext{
88 Information Note from the President to the Commission, 'Better Regulation and Enhanced Impact Assessment', 28 June 2007, SEC(2007) 926.

${ }^{89}$ A Garde, 'Freedom of Commercial Expression and Public Health Protection in Europe' in C Barnard and O Odudu (eds), 12 Cambridge Yearbook of European Legal Studies 2009-2010, 225.

${ }^{90}$ A Garde, 'Advertising Regulation and the Protection of Children-Consumers in the European Union: In the Best Interests of ... Commercial Operators?' in H Stalford et al (eds), Children's Rights in Europe, a Special Issue of the International Journal of Children's Rights 19 (2011) 523.

91 See A Alemanno and A Garde, Regulating Lifestyles in Europe: How to prevent and control noncommunicable diseases associated with tobacco, alcohol and unhealthy diets? (Swedish Institute for European Policy Studies, December 2013) <http://www.sieps.se/sites/default/files/Sieps_2013_7\%20WEBB.pdf>.
} 